\title{
Antisemitismforskning som akademiskt ämne och allmän uppgift
}

\author{
Wolfgang Benz
}

SAMMANDRAG: Utgångspunkten för Wolfgang Benz text är en summering av den forskning som under mer än tre decennier har bedrivits vid Zentrum für Antisemitismusforschung vid Berlins tekniska universitet. Forskningen var till en början mest inriktad på historiska och samtida studier av antisemitism men har under senare år kommit att undersöka rasism som riktar sig mot andra grupper än judar, som till exempel antiziganism eller islamofobi. Benz framhåller att centrumets forskningsparadigm, där en omfattande erfarenhet av empiriska undersökningar av rasism och diskriminering kombineras med en avancerad teoretisk ansats utifrån historiska och sociala förklaringsfaktorers betydelse, kan användas som såväl metodologisk som teoretisk inspirationskälla i andra typer av forskning om samtida rasism eller högerextremism.

NYCKELORD: fördomsforskning; xenofobi; rasism; antisemitism; antiziganism; islamofobi; fördomar som sociala mekanismer.

PUbLICERINGSHISTORIK: Översättning av Benz publicerade avskedsföreläsning "Antisemitismusforschung als akademisches Fach und öffentliche Aufgabe" från Jahrbuch für Antisemitismusforschung I9 (2010).

WOLFGANG BENZ är professor emeritus och före detta chef för Zentrum für Antisemitismusforschung vid Berlins tekniska universitet.

\section{FÖRSLAG PÅ KÄLLANGIVELSE:}

Benz, Wolfgang (2013) "Antisemitismforskning som akademiskt ämne och allmän uppgift", i Det vita fältet II. Samtida forskning om högerextremism, specialnummer av Arkiv. Tidskrift för sambällsanalys, nr 2, s. 167-183.

DoI: http://dx.doi.org/IO.I3068/2000-6217.2.6

(C) original: Wolfgang Benz

(C) svensk version: Wolfgang Benz/Arkiv förlag \& tidskrift 2013

(publicerad I6 september 2013)

Artikeln distribueras enligt en upphovsrättslicens från Creative Commons:

Erkännande-Ickekommersiell-IngaBearbetningar 3.0 Unported, som medger fri ickekommersiell användning och spridning i oförändrat skick så länge källan anges. 
Arkiv. Tidskrift för samhällsanalys är en sakkunniggranskad vetenskaplig tidskrift för samhällsvetenskap och historia. Samtliga artiklar publiceras fritt tillgängliga på:

$$
\text { www.tidskriftenarkiv.se }
$$

(beständig länk, DoI: http://dx.doi.org/IO.I3068/2000-62I7)

Den här artikeln finns tillgänglig i följande format:

PDF \& HTML: via beständig länk, DOI: http://dx.doi.org/IO.I3068/2000-6217.2.6 EPUB: ingår i e-boksutgåva av numret, ISBN: 978 9I 7924254 I TRYCK: ingår i bokutgåva av numret, ISBN: 978 9I 79242558

Grafisk utformning och sidnumrering är identisk i pdf och tryck.

Samtliga artiklar i nr 2 (2013), Det vita fältet II. Samtida forskning om högerextremism, nås via beständig länk, DoI: http://dx.doi.org/I0.13068/2000-6217.2 redaktion för numret: Mats Deland, Paul Fuehrer och Fredrik Hertzberg

Arkiv. Tidskrift för sambällsanalys ISSN: 2000-62I7 (för elektronisk resurs) ISSN: 2000-6225 (för tryckta nummer)

ges ut av

Stiftelsen Arkiv för främjande och spridning av samhällsvetenskaplig och historisk forskning

genom

Arkiv förlag \& tidskrift

Box 1559 SE-22I OI Lund BESÖK: L Gråbrödersg 3 c, ipg TEL: O46-I3 3920

ARKIV FÖRLAG: arkiv@arkiv.nu·www.arkiv.nu TIDSKRIFTEN ARKIV: red@tidskriftenarkiv.se · www.tidskriftenarkiv.se

ANSVARIg UTGIVARE \& CHEFREDAKTÖR: Sven Hort AdMinistrativ Redaktör: David Lindberg ReDAKTörer: Paavo Bergman, Lisa Kings, Zhanna Kravchenko 


\title{
Antisemitismforskning som akademiskt ämne och allmän uppgift
}

\author{
WOLFGANG BENZ
}

Vilket förklaringsvärde har en vetenskap som bygger på ett missriktat begrepp, hur kan den bidra till att belysa världen och med vilka definitioner, teorier och metoder ska den arbeta? Detta är frågor som har riktats till den emellanåt kontroversiella antisemitismforskning som sedan I982 bedrivs vid Technische Universität Berlin. ${ }^{1}$

\section{Begrepp och definitioner}

Missuppfattningarna börjar med begreppet "antisemitism", som myntades i slutet av I8oo-talet i syfte att ge en vetenskaplig förklaring till den fanatiska iver som kom till uttryck i hatet mot judar samt strävan efter att annullera judarnas medborgerliga emancipation. "Semiter" kan ses som medlemmar av en etnisk grupp, även om termen i sig konstruerades av språkvetare för att urskilja en semitisk språkfamilj som sträcker sig från assyriska och babyloniska till kanaaneiska, hebreiska, moabitiska, feniciska, eblaitiska och arameiska och som även inkluderar amhariskan. Därmed har begreppet inget att göra med "raser", men det utgjorde ett

I. Denna text från avskedsföreläsningen vid TU Berlin den 2I oktober 20I0 har med tanke på publicering utökats något samt försetts med referenser.

Benz avskedsföreläsning publicerades på tyska som "Antisemitismusforschung als akademisches Fach und öffentliche Aufgabe", i Jahrbuch für Antisemitismusforschung I9 (2010). Den publiceras här med tillstånd av författaren. 
användbart propagandainstrument för den moderna antisemitismen, en rasistisk ideologi vars aversion mot judarna krävde en vetenskaplig täckmantel. Begreppet fick inte enbart ett stort genomslag utan var effektfullt som få andra begrepp ända fram till folkmordet med sex miljoner offer. Eftersom begreppets innebörd i dag har accepterats över hela världen vore det meningslöst att leta efter ett nytt begrepp. Ordet "antisemitism" bör följaktligen accepteras som en överenskommelse om att beteckna judefientlighet i vid bemärkelse med just detta begrepp.

Ordet "antisemitism" tjänar å ena sidan som övergripande begrepp för alla typer av judefientlighet, å andra sidan betecknar det i en mer avgränsad betydelse framväxten av nya, pseudovetenskapliga antijudiska förbehåll under I8oo-talets sista tredjedel. Dessa fördomar bygger inte på religiösa argument utan på påstådda egenskaper och kännetecken hos den judiska rasen. Den moderna formen av antisemitism måste följaktligen ses som väsensskiljd från den äldre, religiöst motiverade antijudaismen (jfr Nipperdey \& Rürup 1972, s. I29-I53; Hoffmann 1994, s. 293-317). Många som har dragit ut i kampen mot judefientlighet missar emellertid denna åtskillnad eftersom deras främsta vapen utgörs av - visserligen berättigade - emotioner samtidigt som den aktuella antisemitismen betecknas som "modern". Dessa personer ägnar föga möda åt definitioner och applåderar närhelst en förment "ny antisemitism" upptäcks som i denna form inte har funnits någonsin tidigare. Frågan vad "antisemitism" egentligen är ställs emellertid inte enbart av de illvilliga som anser att någon judefientlighet inte förekommer, utan möjligen - och enligt denna syn helt befogade - förbehåll gentemot judar; förbehållens upphov ska sökas hos judarna själva. Med eftertänksamma huvudskakningar konstaterar även intellektuella experter, som har fått uppdraget att uttala sig inför mediernas kameror, att man till att börja med noggrant måste definiera vad antisemitism betyder när man ombeds kommentera en otrevlig händelse. Om receptionen av vetenskap var mer allmän skulle frågan "men vad är egentligen antisemitism?" inte behöva ställas gång på gång eftersom det finns definitioner som är användbara för dagligt bruk.

Ett passande policyinstrument utgörs av följande arbetsdefinition som har föreslagits av European Monitoring Centre on Racism and Xeno- 
phobia och OSSE:s (Organisationen för säkerhet och samarbete i Europa) människorättsorganisation:

Antisemitism är en viss uppfattning om judar, som kan uttryckas som hat mot judar. Retoriska och fysiska uttryck för antisemitism riktas mot judar eller ickejudar och/eller deras egendom, mot judiska gruppers institutioner samt religiösa byggnader och platser.

Därtill kan sådana uttryck även rikta sig mot staten Israel, uppfattad som ett judiskt kollektiv. Antisemitismen riktar återkommande anklagelser mot judar för att konspirera i syfte att skada mänskligheten och används ofta för att skuldbelägga judar för "saker som går fel”. Antisemitismen uttrycks i tal, skrift, visuella former och handlingar, och använder sig av illvilliga stereotyper och föregivna negativa karaktärsdrag. ${ }^{2}$

I modernt språkbruk avses med antisemitism alla judefientliga kommentarer, tendenser, ressentiment, attityder och handlingar oberoende av deras religiösa, rasistiska, sociala eller andra motiv. Mot bakgrund av erfarenheterna av den nazistiska ideologin och maktutövningen måste antisemitism uppfattas som ett socialt fenomen, vilket kan användas som paradigm för bildandet av fördomar samt den politiska exploateringen av fiendebilder som bygger på dessa fördomar. ${ }^{3}$

\section{Fördomar och stereotyper}

Tvärvetenskapliga forskningsresultat visar att judefientlighet är projiceringen av egna fördomar på en minoritet (Benz \& Eder King 2002). Denna projicering har olika funktioner och fördelar för majoriteten. Det bör noteras att det inte finns någon som helst överensstämmelse mellan "juden" såsom den åsyftas och bekämpas av antisemiten och faktiskt existerande judar. De antisemitiska fördomarnas historia bevisar att vrång-

2. Från European Forum on Antisemitism:

http://www.european-forum-on-antisemitism.org/working-definition-of-antisemitism/ svenska-swedish (is februari 2013).

3. Benz använder i sin text förutom begreppet "antisemitism" även "judefientlighet" (Judenfeindschaft), "fientlighet mot judar" (Feindschaft gegen Juden) och "hat mot judar" (Judenhass, Hass aufJuden) som synonymer. Översättningen följer i möjligaste mån Benz språkanvändning, dock har Judenfeindschaft (och adjektivet judenfeindlich) i vissa fall översatts med "antisemitism" respektive "antisemitisk" i syfte att underlätta läsförståelsen. Övers. anm. 
bilden är en seglivad skapelse, det äldsta sociala, kulturella och politiska ressentimentet över huvud taget. Judefientlighetens aktuella manifestationer är varierande och uppvisar nationella särdrag, som den sekundära antisemitismen i Tyskland och Österrike vars argument är inriktade på kompensations- och skadeståndsutbetalningar med anknytning till förintelsen. Rasistiskt motiverad antisemitism, och det därmed sammanhängande förnekandet av förintelsen, figurerar alltid i högerextrema sammanhang. Dess spridning är allomfattande men har olika intensitet.

Den religiösa antijudaismen och dess traditionella utformning (anklagelsen om ansvar för Jesus död, legender om ritualmord) får i jämförelse med vad som är fallet i Västeuropa ett större gensvar i östeuropeiska samhällen. Ett akut problem är antisionismen, vilken i sig inte bör likställas med antisemitism, men som genom sitt fanatiska ställningstagande mot Israel och genom övertagandet av judefientliga stereotyper och argumentationsmönster ("strävan efter världsherravälde", konspirationsfantasier) har utvecklats till en aktuell variant av judefientlighet vilken för närvarande har fått en mycket stor spridning.

Mellanösternkonflikten fick i och med den andra intifadan en dimension som ligger långt ifrån konfliktens egentliga arena i Israel/Palestina. Unga muslimers solidarisering med det palestinska folket i stater där en relativt stor andel av befolkningen har en arabisk-muslimsk bakgrund, som till exempel Frankrike, Belgien, Nederländerna och Storbritannien, manifesterar sig inte enbart i Israelfientlig propaganda, demonstrationer eller till och med kravaller, utan även i en instrumentalisering av traditionell antisemitism. I Östeuropa används judefientlighet som ledmotiv när den nationella majoriteten ska definiera sig själv. Fördomen mot judar fungerar som katalysator för nationella och fundamentalistiska strömningar och bildar en gemensam nämnare för antiliberala, antikapitalistiska, antikommunistiska och upplysningsfientliga rörelser.

Ressentimentet gentemot judar har djupa rötter i den kristna självförståelsen och på grund av denna mycket långa, samhälleliga tradition måste varje försök att förstå dagens judefientlighet även ta antisemitismens historia i beaktande. Kritiker av den akademiska forskningen om antisemitism frestas att i kampen om tolkningsföreträdet avfärda antisemitismforskning som en uteslutande historiskt inriktad vetenskap, vilken 
enbart intresserar sig för "döda judar" samtidigt som den blundar för den dagsaktuella diskrimineringen av judar i Tyskland eller hotet mot staten Israel. Framförda som provokation har dessa anklagelser möjligtvis en viss verkan eftersom de understödjer vissa ressentiment, dock utan att motsvara verkliga förhållanden.

\section{Kampen om tolkningsföreträdet}

Misstänksamheten mot akademiska studier av ämnet "judefientlighet" uttalas från diametralt motsatta politiska läger. När det gäller att mobilisera ett motstånd mot oönskade forskningsresultat kan vänsterradikala, konservativa och högerextrema mötas på några enstaka punkter. Andra handlar i egen sak. Enbart det faktum att det i Berlin finns ett "centrum för antisemitismforskning" oroar en äldre herre så till den grad att han gör sig besväret att i tre långa, handskrivna brev meddela sin åsikt om "judarna" till centrumets föreståndare. ${ }^{4}$ Hans utläggningar har delats in $\mathrm{i}$ 26 punkter och i ett brev från den 22 mars 2009 tar han redan i sin första punkt upp "Sions vises protokoll", vilket bevisar hur hårdnackade och seglivade stereotypa föreställningar kan vara: "Ni styrker", skriver den uppenbarligen bildade mannen, "beviset för förfalskningen av protokollen enbart med ett rättsligt beslut från Schweiz på 1930-talet. Eftersom rättsprocessen av allt att döma har initierats av judarna själva var målet förmodligen att skingra alla tvivel och undanröja alla obehagligheter en gång för alla. Möjligheten av ett partiskt eller felaktigt domslut belyser Ni inte".

Brevets författare syftar på en publikation om "Sions vises protokoll" - en av antisemitismens centrala historiska skrifter med stor påverkan än i dag - i vilken det konspirationsteoretiska tänkandets verkanshistoria och aktualitet betraktas som en av judefientlighetens centrala kategorier. Rättsprocessen i Bern nämns emellertid enbart i förbigående (Benz 2007). Brevet tydliggör inte bara fixeringen vid vissa positioner och argumentationsmönster, utan även kontinuiteten i den vardagliga antisemitiska diskursen samt tonvikten på emotioner: "Enbart det faktum, att det här hos oss i Berlin finns ett centrum för antisemitismforsk-

4. Brevet finns i Archiv des Zentrums für Antisemitismusforschung, TU Berlin. 
ning, tillåter spekulationer som inte kan vara bra för själva syftet, vilket enligt min åsikt även visas av mina resultat”. Den lika utbredda som förenklade argumentationen använder framför allt välkända stereotyper från Mellanösternkonflikten och ämnar bevisa att det när allt kommer omkring måste vara judarnas fel att de inte gillas av någon. Hypotesen att fientligheten mot judar är en konstruktion av majoritetssamhället och att den har instrumentella funktioner tillbakavisas med indignation. Även detta hör till antisemitismforskningens vardag. Reaktionerna på den före detta förbundsdagsledamoten Martin Hohmanns tal i den tyska förbundsdagen visade detta inför allmänheten för några år sedan. ${ }^{5}$

Centrumet för antisemitismforskning uppfattas av en del som en offentlig institution eller åtminstone som en inrättning som får stöd av den tyska regeringen. Andra tror att centrumet tillhör de talrika aktivistgrupper som kämpar mot Israels fiender. Ytterligare en grupp använder internetforum och tidningar som Jerusalem Post som plattform för kampanjer där centrumet förebrås att det inte ensidigt tar ställning för deras intressen. Centrumet är ett oberoende akademiskt forskningsinstitut vid Berlins tekniska universitet (TU) och dess goda anseende över hela världen grundar sig inte på politiska uppdrag, deltagandet i kampanjer eller aktivism, utan på dess egen forskning. Forskningen omfattar studier om den aktuella judefientligheten bland muslimer; forskning om förintelsen; en historisk belysning av räddningen av judar under nazitiden i sju band; en uttömmande redogörelse för koncentrationslägren i nio band samt en handbok om antisemitism i flera band där fientlighet mot judar i alla dess former och uttryck beskrivs utan tidsmässiga eller geografiska begränsningar, från antiken fram till våra dagar, från Martin Luther till Mahmoud Ahmadinejad.

Att detta centrum för forskning om judefientlighet etablerades i just Tyskland har många orsaker. Forskningen är inriktad på observation och

5. Benz syftar här på kristdemokraten Martin Hohmanns mycket omdebatterade tal i tyska förbundsdagen som han höll med anledning av Tag der Deutschen Einheit ("Tyska enhetens dag") den 3 oktober 2003. I detta tal tillskrev Hohmann judarna ett ansvar för kommunismens förbrytelser och offer genom att använda den stereotypa föreställningen om den judiska bolsjevismen. Hohmann framhöll vidare att den kollektiva anklagelsen mot tyskarna som förövare lika gärna kunde riktas mot judarna på grund av deras ansvar för kommunismens brott. Hohmann uteslöts på grund av talet ur CDU. Övers. anm. 
analys av nutida antisemitism, på bilden av Israel i den allmänna opinionen men också på grundläggande forskning om fördomars väsen. Tysklands politiska kultur och historiska arv påkallar denna granskning av judefientlighet på universitetsnivå. Betydelsen av demokrati och tolerans som grundvalar för mänsklig samexistens hör till nazitidens viktigaste lärdomar. Detta nödvändiggör en ständig belysning av samhället när det gäller dess mest känsliga punkt, majoritetens attityd gentemot den judiska minoriteten och judar i största allmänhet.

\section{Teorier om judefientlighet}

Antisemitismforskningens tvärvetenskapliga karaktär är inte bara avgörande för ämnets metodologiska pluralism utan också för dess många förklaringsmodeller (Strauss \& Bergmann 1987-1993; Rensmann 1998; Claussen 1987). Mångfalden av antisemitismteorier har en motsvarighet i fenomenets olika manifestationer. Historiska tolkningar som sträcker sig tillbaka till antikens fientlighet mot judar (Yavetz 1997) har på många sätt en vägledande roll. Historisk forskning framställer betydelsen av I8oo-talets "moderna antisemitism" som reflex av en modernitetskris (Erb \& Bergmann 1989; Volkov 1994), i vilken mycket olika influenser, traditioner och strukturer samverkar i reaktionen på sociala omstruktureringar samt det borgerliga samhällets värde- och legitimitetsproblem. Nation och nationalism erbjuder en förklaringsmodell för fientlighet mot judar ( $\mathrm{Holz}$ 200I) men även den politiska positioneringen är av betydelse och medför olika karakteristiska former av antisemitism (Brosch m.fl. 2007; Haury 2002). Kristeorin kan tillämpas på olika epoker, såväl industrialiseringsfasen som perioden efter första världskriget samt - delvis - på tiden efter Tysklands återförening. Dessa kristider kännetecknas av betydande sociala spänningar som leder till frustrationer och aggressioner vilka pockar på urladdning och sökande efter objekt som uppfyller funktionen som "skyldig" ("syndabock"-teorin). Rädslan för individuell eller kollektiv statusförlust är grundläggande för krismodellen, under 1990-talets kris i återföreningens spår fick utlänningar (asylsökande såväl som arbetskraftsmigranter bosatta i Tyskland) inta rollen som aggressionsobjekt på samma sätt som judarna under I80o-talets modernitetskris (Salzborn 20IO). 
Psykologiska och psykoanalytiska teorier har sedan länge varit etablerade i antisemitismforskningen. ${ }^{6}$ Läran om den auktoritära personlighetstypen (Adorno 1973; Adorno \& Horkheimer 20I2) och ansatsen om växelverkan mellan frustration och aggression är otänkbara utan den freudianska psykoanalysens vetenskapliga insikter. I samspelet med samhällsvetenskaperna har individfokuserade förklaringsmodeller (auktoritetskonflikt, uppväxttrauman, frustration på grund av inre konflikter) utvidgats till strukturella teorier på gruppnivå där antisemitism definieras som strukturer av fördomar vilka i specifika konfliktsituationer blir betydelsefulla för relationen mellan den (judiska) minoriteten och majoritetssamhället (Benz \& Eder King 2002). Relationella rivaliteter med socialt och etniskt ursprung spelar en viktig roll i dessa förklaringsmodeller och är särskilt användbara i tolkningen av vissa ideologiskt bestämda konflikter som ursprungligen härrör ur konkurrensproblem, som exempelvis xenofobi.

Upplevelsen av resursbrist, eller rädslan för den (ofta i samband med hotande statusförlust), är väsentliga för individens uppfattning av sociala positioner och präglar beteendet gentemot minoriteter, vars värde bedöms som mindre än det egna. Deprivationsteorin förklarar uppkomsten av fördomar och deras effekter med erfarenheter (till exempel av förment välbärgade invandrare) kopplade till minoritetsgruppers sociala rörlighet uppåt och den egna gruppens befarade statusminskning. Dessa erfarenheter tar sig uttryck i negativa stereotyper (jfr Benz 2000, s. III-I2O).

\section{Antisemitism som paradigm}

Monokausala förklaringar kan inte göra rättvisa åt det komplexa fenomenet antisemitism vilket gör det nödvändigt för olika discipliner, metoder och teorier att samverka. Antisemitismen används på grund av sin långa existens och sina varierande manifestationer som exempel när man undersöker gruppkonflikter och sociala fördomar. I och med de nuvarande migrationsprocesserna och utvecklingen av samhällen med stora

6. Jämför de samhällsvetenskapliga och psykoanalytiska bidragen vid det psykiatriska symposiet om antisemitism i New York år 1944: Simmel (1946); Brainin, Ligeti och Teicher (1993). 
etniska minoriteter i Europa upprepas strukturellt sett många av de konflikter och problemställningar som vi känner till från historien om samexistensen mellan judar och icke-judar. Därför kan antisemitismforskningen inte längre begränsas till det snäva ämnet "judefientlighet". Ämnet måste vidgas för att sträcka sig från undersökningar av specifika ressentiment och deras effekter till allmänna och övergripande problem som fördomar och diskriminering, utestängning av minoriteter och xenofobi. Studiet av migrationsprocesser och minoritetskonflikter med hjälp av allmänna och övergripande teoretiska ansatser är därför lika mycket del av antisemitismforskningen som historisk forskning om diskrimineringen och förföljelsen av enskilda sociala, etniska, religiösa eller politiska minoriteter. Målet är en omfattande fördomsforskning som i princip kan omfatta varje lämpligt forskningsområde så länge det motsvarar ämnets paradigmatiska karaktär. Komparativa studier har följaktligen på motsvarande sätt som den metodologiska pluralismen hög prioritet i antisemitismforskningen (Bergmann \& Körte 2004).

I den meningen måste begreppet antisemitism utvidgas och förstås som en forskningsstrategi, som fokuserar på konkreta företeelser som förföljelsen av sinter och romer eller diskrimineringen av minoriteter som exempelvis "asociala", samt på exkluderande ideologier baserade på biologisk determinism, socialdarwinism, rasistiskt antiegalitära strävanden och liknande teorem. Ungdomsvåld, högerextremism och främlingsfientlighet utgör således tematiska forskningsområden i en antisemitismforskning som söker svar på komplexa problemsammanhang och som analyserar varierande fiendebilder och fördomar mot bakgrund av deras politiska, sociala och kulturella sammanhang.

Från första början har antisemitismforskningen vid centrumet i Berlin inte begränsats till att endast undersöka hatet mot judar och detta hats orsaker, former och effekter. I sin installationsföreläsning år 1982 uttryckte Herbert A. Strauss, en av centrumets grundare och dess första verkställande direktör, sin förhoppning att forskningen om antisemitism skulle kunna leda fram till "nya insikter som kan underlätta förståelsen av till exempel arbetsmigranters situation i de västerländska industriländerna”. Strauss lanserade en ny forskningsansats med det övergripande syftet att studera fördoms- och integrationsprocesser samt relationerna mellan 
majoritet och minoritet, ett perspektiv som enligt Strauss, som under nazitiden flydde till USA och bosatte sig där år 1943, är särskilt framträdande i den "amerikanska politiska och sociala kulturen, dess framgångar men också dess bakslag" (Strauss 2002, s. 24). Den av "islamkritikerna" eftersträvade stigmatiseringen av muslimer, som bjöds in till Förbundsrepubliken Tyskland såsom arbetsmigranter och sedermera blev tyska medborgare, är mot bakgrund av den otillräckliga integrationspolitiken ett av de forskningsområden som Strauss utpekade.

Vissa politiska intressenter ifrågasätter antisemitismforskningens status som vetenskaplig disciplin mot bakgrund av aktuella politiska tendenser, främst fixeringen vid hotet mot Israel genom en utbredd och massiv antisionism i den muslimska världen. I olika kampanjer presenteras krav på vetenskapens instrumentalisering som utan några större intellektuella pretentioner är fastlåsta i schematiska indelningar i vänner respektive fiender. Dessa urskiljningslösa kampanjer drar sig inte heller för förtal och kräver att aktörerna intar absoluta och fastlåsta positioner. Vetenskaplig analys och tolkning av problemet antisemitism, som inte underordnas kampanjmakarnas manikeiska världsbild, nedvärderas av dessa fanatiker som anser att studiet av diskrimineringsmekanismer, som berör andra minoriteter än den judiska, är otillåtligt, i synnerhet när antisemitismforskningens insikter används paradigmatiskt. Denna användning uppfattas av vissa politiska och publicistiska aktörer som en relativisering av den naturligtvis fruktansvärda antisemitismen. Det enfaldiga argument som framförs mot en paradigmatisk användning av antisemitismforskningens metoder och resultat är att denna typ av jämförelser (till exempel av antisemitismens traditionella praktiker med "islamkritikernas" tillvägagångssätt) nedvärderar det ena fenomenet samtidigt som det andra fenomenet uppvärderas. Men antisemitismforskningen marginaliserar ingalunda förintelsen om den fokuserar på diskrimineringsstrategier som först användes av antisemiter mot judar för att senare användas av islamofober gentemot muslimer.

Anspråket på tolkningsföreträdet när det gäller antisemitismens egentliga väsen, samt vem som har rätt att forska kring antisemitism, framförs med olika motiveringar. Moraliska och filosofiska argument presenteras främst när det handlar om politiska, men ibland även ekonomiska, 
intressen. Filosemitism och moralisk bestörtning utgör lika lite som en naiv politisk hållning lämpliga instrument för att hantera, det vill säga utforska och bekämpa, detta otäcka fenomen. Detsamma gäller för initiativ för att studera antisemitism som har initierats av olika parlament, nationella regeringar eller internationella organ. Dessa börjar vanligtvis med ett försök att definiera antisemitism på nytt, gärna genom att lokalisera judefientligheten hos andra grupper än den egna, och avslutas i regel efter några spekulativa antaganden med olika typer av resolutioner. Insikten att antisemitismen som fenomen (som inställning, som hållning, som trossats, som vapen) inte kan bringas ur världen med så pass enkla medel behöver ändå inte sluta i uppgivenhet. Målet bör snarare vara att förstå judefientlighet som ett socialt fenomen som kan motarbetas med hjälp av upplysning, att bannlysa antisemitismen ur offentligheten samt att marginalisera den politiskt.

Trots dessa insikter är det fortfarande svårt att tydliggöra det faktum att antisemitism på inget sätt är en reaktion på judars karaktärsegenskaper eller handlingar utan en konstruktion av majoritetssamhället, som utifrån intressen och politiska mål utformar en bild av juden. Det förefaller lika svårt att redogöra för nödvändigheten av antisemitismforskning som vetenskaplig disciplin. Vetenskap innebär analys och interpretation av ett sakförhållande med rationella metoder där målet är objektivitet. Max Weber framförde i en klassisk formulering kravet på en kombination av passion och omdöme som avgörande förutsättning för politisk eller vetenskaplig handling. Detta är fortfarande sant. Tanken att en fanatisk antisemit kan bedriva fruktbar forskning om antisemitism är fullständigt absurd. Empati med den minoritet som forskaren undersöker utgör en självklar förutsättning för hennes forskning. Vid sidan om all nödvändig passion för ämnet innebär kravet på omdömesförmåga att antisemitismforskarens motivation inte främst bör vara att söka efter bifall från vissa grupper i den undersökta minoriteten. Antisemitismforskning är en allmännyttig tjänst till majoritetssamhället, inte ett inställsamt försök att bli vän med offren för antipati, aggression, diskriminering och förföljelse. Syftet med antisemitismforskning är således att upplysa majoriteten om ursprung, utformning, effekter och konsekvenser av en fientlig inställning gentemot judar som härrör ur hat, beräkning och tradition. 


\section{Antisemitismforskningens vägledande roll}

Uppmaningen till att inkludera fientlighet mot andra minoriteter och stigmatiserade grupper i en antisemitismforskning som på ett paradigmatiskt sätt har utvecklat en bred uppsättning undersökningsmetoder, vilka dessutom kontinuerligt vidareutvecklas, innebär samtidigt ett avståndstagande från en akademisk institutionalisering av speciella forskningsämnen som antiziganism eller islamofobi. ${ }^{7}$ Inte för att en sådan forskning inte skulle behövas, tvärtom. Samtidigt som försöken att instrumentalisera forskningsområdet utifrån specifika gruppers särintressen måste tillbakavisas kan en uppsplittring av forskningen om fördomar i många olika mikronivåer medföra andra negativa konsekvenser eftersom en sådan uppsplittring ofrånkomligen leder till resursbrist. Dessutom riskerar forskningen att tappa sitt fokus på den övergripande samhälleliga kontexten.

Den mer avgränsade antisemitismforskningens vägledande roll som forskning om fördomar i vidare bemärkelse härrör ur det faktum att judefientlighet är den äldsta ännu existerande politiska, religiösa, sociala och ekonomiska fördomen, med mänsklighetens största folkmord som katastrofal konsekvens. Tvärtemot vad högljudda belackare hävdar minskar inte heller betydelsen av judar och antisemitism när antisemitismforskningen granskar andra minoriteter. Tänkbara skäl bakom dylika illvilliga anklagelser är en grundläggande misstänksamhet gentemot vetenskap, upplevelsen av konkurrens mellan olika offergrupper eller en allmän oro för minskande empati. En forskning om fördomar som har en tydlig strategi för att utröna tillvägagångssättet och bedöma det hat mot en minoritet som utmynnade i förintelsen, innebär ingen marginalisering. På samma sätt som jämförande folkmordsforskning inte ifrågasätter förintelsens unika status är en komparativ fördomsforskning, som tar sin utgångspunkt i antisemitismforskningen, på intet sätt ett uttryck för en bagatellisering av vare sig det historiska eller det nuvarande hatet mot judar.

7. Begreppet "islamofobi" framkallar hos somliga "islamkritiker" en omotiverad och grundlös hysterisk reaktion. För en översikt om detta forskningsämnes etablering samt det specifika begreppet islamofobi, jämför den nyligen instiftade årsboken för islamofobiforskning med Farid Hafez som redaktör (Jahrbuch für Islamophobieforschung, 2010-); se även Benz (2009). 


\section{Empati, känslor, intressen}

Två bestämmande faktorer utgör förutsättningen för alla typer av studier av antisemitism. Den första faktorn är förintelsen som ett mene tekel, ett illavarslande tecken för hur ressentiment mot en minoritet kan sluta i mord. Det trauma som förintelsen vållar hos offren och deras avkomlingar kan inte preskriberas, lika lite som skammen hos förövarnas avkomlingar. Den andra bestämmande faktorn är förhållandet till Israel, judarnas stat, vars enskilda handlingar naturligtvis måste kunna kritiseras på samma sätt som när det gäller andra stater, men vars existensrätt inte är förhandlingsbar.

Den andra intifadan mot Israel, terrorattacken II september 200 I samt den iranska diktatorn Ahmadinejads skrävel och vapenskrammel har medfört mycket negativa effekter på västvärldens förnuft och liberalism. Populister och oansvariga demagoger försöker övertyga världen om att alla som tror på en specifik religion, nämligen islam, är suspekta av ett enda skäl: att de är muslimer. Intolerans mot muslimer propageras av många och propagandan framhåller att väst måste skydda sig mot islam eftersom religionen är aggressiv och eftersom det egentligen inte är en religion, utan en politisk rörelse som sedan århundraden tillbaka kämpar mot "västvärlden" och mot Europa, det vill säga den kristna civilisation som islam hotar att dominera. Bland det mest deprimerande i utvecklingen dessa dagar är det faktum att denna antimuslimska agitation inte är begränsad till de högerextrema kretsar, där man kan förvänta sig liknande föreställningar och där denna propaganda har utvecklats och fortfarande utgör en kärnfråga. Med hjälp av begreppet "islamkritik" har dess överspända föreställningar omslutits av publicister, forskare och politiker, det vill säga personer av vilka man borde kunna förvänta sig mer rationalitet och tolerans. Oroväckande är inte enbart de traditioner som åberopas, utan framför allt de metoder med vars hjälp man agiterar för sin sak.

\section{Rädslor för hot och deras traditioner}

Antisemitismen iscensätts och instrumentaliseras genom fördomar och stereotypa bilder av judar. Detsamma gäller även för inställningen till andra minoriteter. När en undersökning visar att 80 procent av tyskarna 
uppfattar islam som en "fanatisk och våldsam religion" (jfr Naumann 2009, s. 19) beror denna uppfattning varken på ett studium av religionens innehåll och doktriner eller på kunskap om Koranen och sunna samt islams historia och kultur. I stället avspeglar opinionsundersökningen rädsla och motvilja, stimulerad av ressentiment vars tradition går långt tillbaka i tiden. Den stereotypa uppfattningen av en annan kultur, i dag kraftigt underblåst av demagoger, bygger således på traderade konnotationer och associationer som bildar argumentationens kärna i diskursen om islam. Dessa grundläggande vanföreställningar om islam ifrågasätts inte längre eftersom de betraktas som en beståndsdel av vedertagen, traderad "kunskap".

Hotbilden om "Europas islamisering" (jfr Königseder 2008, s. 17-44; Widmann 2008, s. 45-68) som frambesvärjs med större passion än objektiv expertis kommer till uttryck i debatten om slöjförbud. Samma hotbild artikuleras i kravet på förbud av minareter eller hätska tirader i bloggosfären och den faller tillbaka på sekelgamla tolkningsmönster. Fientligheten mot islam argumenterar sedan medeltiden utifrån simpla teser om behovet av motvärn. Med hjälp av polemik mot Koranen svartmålas islam som omänsklig, både som religion och som kultur, samtidigt som alla muslimer tillskrivs negativa egenskaper genom kulturrasistiska postulat. Strategin för denna anti-islamiska diskurs går ut på att framställa "islam" som en enhetlig företeelse och islamistisk terror som typisk. Den aktuella "islamkritiska" diskursen kännetecknas av betydande främlingsfientliga och kulturrasistiska drag som är kopplade till rädslan för att en omfattande invandring leder till en utplåning av den egna kulturen. Egendomligt nog argumenteras i detta sammanhang genomgående med hjälp av religiösa förbehåll vilka med stort allvar presenteras för, och uppenbarligen delas av, Europas sekulariserade samhällen. Dessa föreställningar om despoti (som börjar redan i familjelivet), våldsbenägenhet och ovilja att utbilda sig har en lång historisk tradition. Föreställningarna bekräftas genom hänvisningar till den nutida islamiska terrorismen och den teokratiska diktaturen i Iran, en stat som på grund av sitt terrorvälde och sina hot mot andra stater är diskrediterad sedan länge.

Alltsedan Konstantinopels fall år I453, och sedan turkarna år I 527 för första gången belägrade Wien, tillhör rädslan för islams hot mot väst- 
världen de gängse stereotyper som vid behov kan aktualiseras i konkreta hotbilder (jfr Mosser 20I0, s. 297-318). ”Turkarna” framställdes under högmedeltiden i egenskap av muslimer som själva sinnebilden av den kristna västvärldens fiender. I dag glömmer många bort att turkarna tilldelades denna roll under skapandet av fiendebilden "muslimer", vilken i sin tur ingick i antisemitismens övergripande konspirationsteoretiska kontext. Till exempel förknippades anklagelserna om att judar hade förgiftat brunnar i södra Frankrike år I32I med beskyllningen att det var muslimerna som hade anstiftat dem. Under reformationstiden fanns det bland de vanliga anklagelserna mot judar, som tog sig konkreta uttryck i legenderna om ritualmord, hostieskändning och förgiftning av brunnar, även föreställningar om att judarna var i maskopi med djävulen och hade ingått en hemlig pakt med turkarna. I dagsläget är det svårt att föreställa sig en koalition på mer spekulativa grunder. Den aktuella kritiken mot islam, såsom den med eftertryck framförs även från judiskt håll (av förståeliga skäl, med tanke på hotet mot staten Israel och många muslimers aggressivt framförda antisemitism), har inget historiskt minne och den visar inte heller några tecken på medvetenhet om problemet att stigmatiseringen av olika grupper är utbytbar. I fixeringen vid sin fiendebild måste populister rasa mot differentierande betraktelsesätt för att kunna bevara sin endimensionella världsbild. Ur vetenskaplig synpunkt är det obestridligt att islamofobi, det vill säga demagogisk fientlighet mot islam som predikar intolerans och hat mot en främmande kultur, är jämförbar med andra antihumanistiska traditioner som exempelvis antisemitism och antiziganism.

Den person som tar upp detta, till exempel genom att hänvisa till parallellerna med den organiserade antisemitismens agitation mot judarnas emancipation i Tyskland i slutet av I8oo-talet, måste vara beredd på ett förskräckligt rabalder eftersom hon eller han påstås ha satt ett likhetstecken mellan islamofobi och antisemitism. Vad det verkligen handlar om ignoreras därmed fullständigt. Det handlar om tolerans i ett demokratiskt samhälle, om en strävan såväl efter att förstå diskrimineringen och marginaliseringen av minoritetsgrupper som att förebygga den. Det handlar också om att lära sig från antisemitismens historia. Alla ansträngningar att utforska och förstå förintelsen, i syfte att 
använda erfarenheterna från detta katastrofala massmord på judar för att utveckla ett demokratiskt, humanistiskt och tolerant samhälle, är förgäves om stigmatiseringen av judar byts ut mot stigmatiseringen av en annan grupp. Just denna praktiska användbarhet är emellertid poängen med en antisemitismforskning som inte går i specifika intressegruppers ledband, utan som utöver det rent akademiska kunskapssökandet också vill erbjuda en tjänst till hela samhället.

\section{Översättning: Paul Fuehrer}

\section{Referenser}

Adorno, Theodor W. 1973. Studien zum autoritären Charakter. Frankfurt: Suhrkamp.

Adorno, Theodor W. \& Horkheimer, Max 2012. Upplysningens dialektik. Filosofiska fragment. Göteborg: Daidalos.

Benz, Wolfgang 2000. Antisemitismusforschung, i Brenner, Michael \& Rohrbacher, Stefan (red.) Wissenschaft vom Judentum. Annäherungen nach dem Holocaust. Göttingen: Vandenhoeck \& Ruprecht.

Benz, Wolfgang 2007. Die Protokolle der Weisen von Zion. Die Legende von der jüdischen Weltverschwörung. München: Beck.

Benz, Wolfgang (red.) 2009. Islamfeindschaft und ihr Kontext. Dokumentation der Konferenz "Feindbild Muslim - Feindbild Jude". Berlin: Metropol.

Benz, Wolfgang \& Eder King, Angelika (red.) 2002. Judenfeindschaft als Paradigma. Studien zur Vorurteilsforschung. Berlin: Metropol.

Bergmann, Werner \& Körte, Mona (red.) 2004. Antisemitismusforschung in den Wissenschaften. Berlin: Metropol.

Brainin, Elisabeth, Ligeti, Vera \& Teicher, Samy 1993. Vom Gedanken zur Tat. Zur Psychoanalyse des Antisemitismus. Frankfurt: Brandes \& Apsel.

Brosch, Matthias m.fl. (red.) 2007. Exklusive Solidarität. Linker Antisemitismus in Deutschland. Berlin: Metropol.

Claussen, Detlev 1987. Grenzen der Aufklärung. Zur gesellschaftlichen Geschichte des modernen Antisemitismus. Frankfurt: Fischer Taschenbuch.

Erb, Rainer \& Bergmann, Werner 1989. Die Nachtseite der Judenemanzipation. Der Widerstand gegen die Integration der Juden in Deutschland I780-1860. Berlin: Metropol.

Haury, Thomas 2002. Antisemitismus von links. Kommunistische Ideologie, Nationalismus und Antizionismus in der frühen DDR. Hamburg: Hamburger Ed.

Hoffmann, Christhard 1994. Christlicher Antijudaismus und moderner Antisemitismus. Zusammenhänge und Differenzen als Problem der historischen Antisemitismusforschung, i Siegele-Wenschkewitz, Leonore (red.) Christlicher Antijudaismus und Antisemitismus. Theologische und kirchliche Programme Deutscher Christen. Frankfurt: Haag \& Herchen. 
Holz, Klaus 200I. Nationaler Antisemitismus. Wissenssoziologie einer Weltanschauung. Hamburg: Hamburger Ed.

Königseder, Angelika 2008. Feindbild Islam. Jahrbuch für Antisemitismusforschung 17.

Mosser, Ruth Orli 2oro. Abendland in Christenhand. Zur antimuslimischen WahlkampfRhetorik der FPÖ unter Heinz-Christian Strache. Jahrbuch für Antisemitismusforschung 19.

Naumann, Thomas 2009. Feindbild Islam. Historische und theologische Gründe einer europäischen Angst, i Schneiders, Thorsten Gerald (red.) Islamfeindlichkeit. Wenn die Grenzen der Kritik verschwimmen. Wiesbaden: VS Verlag für Sozialwissenschaften.

Nipperdey, Thomas \& Rürup, Reinhard 1972. Antisemitismus, i Brunner, Otto, Conze, Werner \& Koselleck, Reinhart (red.) Geschichtliche Grundbegriffe. Historisches Lexikon zur politisch-sozialen Sprache in Deutschland, 1972-1992, band I. Stuttgart: Klett.

Rensmann, Lars 1998. Kritische Theorie über den Antisemitismus. Studien zu Struktur, Erklärungspotential und Aktualität. Berlin: Argument.

Salzborn, Samuel 2010. Antisemitismus als negative Leitidee der Moderne. Sozialwissenschaftliche Theorien im Vergleich. Frankfurt: Campus.

Simmel, Ernst (red.) 1946. Anti-semitism. A Social Disease. New York: International Universities Press.

Strauss, Herbert A. 2002. Antisemitismusforschung als Wissenschaft, i Benz, Wolfgang \& Eder King, Angelika (red.) Judenfeindschaft als Paradigma. Studien zur Vorurteilsforschung. Berlin: Metropol.

Strauss, Herbert A. \& Bergmann, Werner (red.) 1987-1993. Current Research on Antisemitism, 3 band. Berlin: Walter de Gruyter.

Volkov, Shulamit 1994. Die Juden in Deutschland 1780-1918. München: R. Oldenbourg Verlag.

Widmann, Peter 2008. Der Feind kommt aus dem Morgenland. Rechtspopulistische "Islamkritik" um den Publizisten Hans-Peter Raddatz suchen die Opfergemeinschaft mit Juden. Jahrbuch für Antisemitismusforschung 17.

Yavetz, Zvi 1997. Judenfeindschaft in der Antike. Die Münchener Vorträge. München: Beck. 


\section{FÖRNUFTETS}

BANEMÄN

Från Nietzsche till Hitler

\section{Georg Lukács}

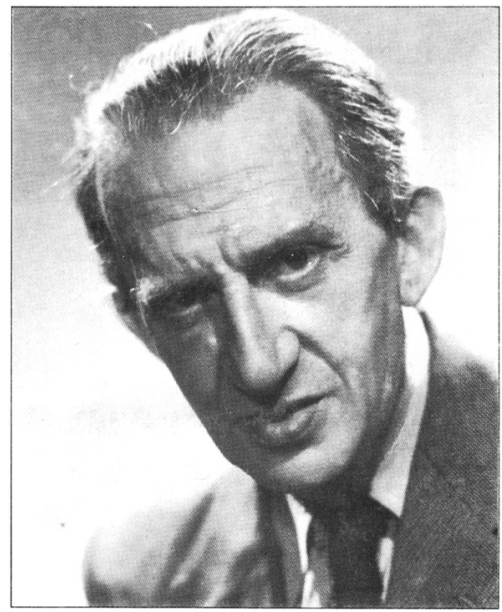

Georg Lukács omskrivna och omstridda frontalangrepp på den tyska filosofiska reaktionen och irrationalismen från 1954, Zerstörung der Vernunft, är fortfarande fascinerande läsning. Med utgångspunkt i devisen "Det finns ingen oskyldig världsåskådning” gör Lukács upp med den intellektuella miljö i Tyskland som han själv som ung befunnit sig i, och som han ansåg bidrog till att bereda vägen för Hitler och nazismen.

Arkiv förlag 1985, inbunden, 320 sidor

Fler böcker av Georg Lukács från Arkiv förlag:

Realismens seger. Litteraturkritiska essäer, Arkiv förlag 1983

Historia och klassmedvetande, Cavefors 1971 (i distribution)

»Böckerna går att beställa i bokhandeln och från www.arkiv.nu« 